\title{
STUDI TENTANG KESADARAN BERPIKIR METAKOGNISI MAHASISWA SEMESTER I JURUSAN PENDIDIKAN MATEMATIKA FKIP UHO
}

\author{
La Misu ${ }^{1}$ \\ ${ }^{1}$ Jurusan Pendidikan Matematika FKIP Universitas Halu Oleo Kendari
}

\begin{abstract}
The purpose of this research are: (1) review awareness metacognition student Math Education University Halu Oleo in general, (2) review awareness metacognition student Math Education University Halu Oleo based on National test scores (UN) mathematics senior high school, (3) review awareness metacognition student Math Education University Halu Oleo based on origin senior high school, and (4) review awareness metacognition student Math Education University Halu Oleo based on gender. Awareness metacognition students consisting of 4 levels namely the level 1: tacit use, level 2: aware use, level 3: strategic use, and level 4: reflective use. Based on the research done concluded that: (1) Generally (53.9\%) Metacognition Awareness students of Mathematics Education University Halu Oleo is at level 1 (tacit use), and a small proportion (12.7\%) were at level 4 (reflective use). (2) Generally (55.82\%) students of Mathematics Education University Halu Oleo which has a value National test scores (UN) of math between 70 and 90 , and only $13.95 \%$ gain UN math $\geq 90$. Value UN Math student $<90$, generally remained at level 1 (tacit use), while the value of UN math students $\geq 90$ to generally already be at level 4 (reflective use). (3) Generally (53.97\%) students of Mathematics Education University Halu Oleo reside outside the city. And from students who live outside the city, mostly $(61.77 \%)$ metacognitive awareness of students remained at Level 1 (tacit use), and only $2.94 \%$ are at level 4 (reflective use). While students who live in the city, the level of awareness metacognition of students are at Level 1 (tacit use) only $44.83 \%$ ), and at level 4 (reflective use) there are $24.14 \%$. And (4) Generally (63.49\%) from students of Mathematics Education University Halu Oleo are women. While the level of awareness of student metacognition between men and women are relatively equal.
\end{abstract}

Keywords: Metacognition Thinking Awareness, students the first half of

FKIP Universitas Halu Oleo Kendari

Email: lamisuhamid@yahoo.co.id
(C2017 Universitas Islam Negeri Walisongo

ISSN: 2088-7868, e-ISSN 2502-5708 


\begin{abstract}
Abstrak
Penelitian ini bertujuan untuk (1) meninjau kesadaran metakognisi mahasiswa Jurusan Pendidikan Matematika FKIP UHO secara umum, (2) meninjau kesadaran metakognisi mahasiswa Jurusan Pendidikan Matematika FKIP UHO berdasarkan nilai UN Matematika di SMA, (3) meninjau kesadaran metakognisi mahasiswa Jurusan Pendidikan Matematika FKIP UHO berdasarkan asal SMA, dan (4) meninjau kesadaran metakognisi mahasiswa Jurusan Pendidikan Matematika FKIP UHO berdasarkan jenis kelamin. Kesadaran metakognisi mahasiswa terdiri atas 4 tingkatan/level yakni level 1 (tacit use), level 2 (aware use), level 3 (strategic use), dan level 4 (reflective use). Berdasarkan hasil penelitian disimpulkan bahwa: (1) Umumnya $(53,9 \%)$ Tingkat Kesadaran Metakognisi mahasiswa Jurusan Pendidikan Matematika FKIP UHO berada pada level 1 (tacit use), dan sebagian kecil $(12,7 \%)$ berada pada level 4 (reflective use). (2) Umumnya (55,82\%) mahasiswa Jurusan Pendidikan Matematika FKIP UHO yang memiliki nilai UN matematika antara 70 sampai 90 , dan hanya 13,95\% memperoleh nilai UN matematika 90 ke atas. Dari nilai UN matematika mahasiswa yang kurang dari 90, umumnya masih berada pada level 1 (tacit use), sedangkan nilai UN matematika mahasiswa 90 ke atas umumnya sudah berada pada level 4 (reflective use). (3) Umumnya (53,97\%) mahasiswa Jurusan Pendidikan Matematika FKIP UHO berdomisili di luar kota. Dan dari mahasiswa yang berdomisili diluar kota tersebut, umumnya $(61,77 \%)$ tingkat kesadaran metakognisi mahasiswa masih berada pada Level 1 (tacit use), dan hanya 2,94\% berada pada level 4 (reflective use). Sedangkan mahasiswa yang berdomisili di kota, tingkat kesadaran metakognisi mahasiswa yang berada pada Level 1 (tacit use) hanya 44,83\%), dan pada level 4 (reflective use) ada 24,14\%. Dan (4) Umumnya (63,49\%) mahasiswa Jurusan Pendidikan Matematika FKIP UHO adalah perempuan. Sedangkan tingkat kesadaran metakognisi mahasiswa antara laki-laki dan perempuan relatif sama.
\end{abstract}

Kata Kunci: Kesadaran Metakognisi, Mahasiswa Semester I

\title{
PENDAHULUAN
}

Pada awalnya, praktik pembelajaran di Program Studi Pendidikan Matematika Jurusan P.MIPA FKIP UHO cenderung dilakukan secara konvensional yaitu melalui teknik komunikasi oral. Praktik pembelajaran konvesional semacam ini lebih cenderung menekankan pada bagaimana dosen mengajar (teacher-centered) dari pada bagaimana mahasiswa belajar (student-centered), dan secara keseluruhan hasilnya tidak banyak memberikan kontribusi bagi peningkatan mutu proses dan hasil belajar mahasiswa.

Berdasarkan pengalaman penulis dalam mengajarkan matematika dasar (kalkulus), umumnya mahasiswa dalam menyelesaikan masalah matematika kebanyakan hanya menghafal rumus turunan ataupun menghafal tehnik pengintegralan. Jarang sekali mahasiswa menyelesaikan masalah turunan dan integral berdasarkan 
konsep. Hal ini dapat dilihat dari hasil jawaban mahasiswa bila menyelesaikan soal di depan kelas maka mahasiswa kebingungan dalam mengemukakan ide awal penyelesaian. Kadang juga ide awalnya sudah ada tapi mahasiswa kebingungan untuk melanjutkan langkah berikutnya. Kadang-kadang juga mahasiswa bisa menyesaikan secara tuntas soal turunan atau integral, tapi mereka belum mampu mengungkapkan alasan setiap langkahnya. Padahal, dalam proses pembelajaran selalu diberikan konsep turunan dan integral dan contoh penyelesaian turunan dan integral berdasarkan konsepkonsep turunan dan integral. Hal ini sesuai hasil penelitian Utu Rahim dan La Misu (2015) bahwa umumnya mahasiswa Jurusan Pendidikan Matematika FKIP UHO belum mampu menjelaskan dan memberi alasan setiap langkah dalam menyelesaikan masalah integral.

Oleh karena itu, dalam penelitian ini penulis mencoba melihat kesadaran metakognisi mahasiswa dalam menyelesaikan masalah matematika dasar (Kalkulus). Dengan kata lain, melihat kesadaran mahasiswa menggunakan pemikirannya dalam memberikan alasan-alasan yang formal terhadap semua permasalahan turunan dan integral. Hal ini berdasarkan pendapat Biryukov (2003) bahwa konsep metakognisi merupakan dugaan pemikiran seseorang tentang pemikirannya yang meliputi pengetahuan metakognitif (kesadaran seseorang tentang apa yang diketahuinya), keterampilan metakognitif (kesadaran seseorang tentang sesuatu yang dilakukannya) dan pengalaman metakognitif (kesadaran seseorang tentang kemampuan kognitif yang dimilikinya).

Kesadaran metakognisi mahasiswa yang dimaksud dalam penelitian ini seperti dikemukakan oleh Swartz dan Perkins (1990) bahwa tingkat kesadaran seseorang dalam proses berpikir meliputi:

Level 1: tacit use, merupakan jenis berpikir dalam membuat keputusan tanpa berpikir tentang keputusan tersebut. Siswa hanya mencoba atau asal menjawab dalam memecahkan soal.

Level 2: aware use, merupakan jenis berpikir yang menunjukkan seseorang menyadari "apa" dan"kapan" dia melakukan sesuatu. Siswa menyadari segala sesuatu yang dilakukan dalam memecahkan masalah.

Level 3: strategic use, merupakan jenis berpikir yang menunjukkan mengorganisasi pemikirannya dengan menyadari strategi-strategi khusus yang meningkatkan ketepatan 
berpikir. Siswa mampu menggunakan dan menyadari strategi yang tepat dalam memecahkan masalah.

level 4 : reflective use, merupakan jenis berpikir yang menunjukkan seseorang melakukan refleksi tentang pemikirannya dengan mempertimbangkan perolehan dan bagaimana memperbaikinya. Siswa mampu menyadari atau memperbaiki kesalahan yang dilakukan.

Pada saat soal atau pertanyaan diberikan, dosen perlu melihat kemampuan mahasiswa dalam menyusun strategi dan langkah berpikir mereka, sehingga tidak hanya melihat kebenaran akhir jawaban siswa. Pada pemecahan masalah terdapat proses yang lebih penting yang harus diketahui oleh dosen, yaitu proses-proses yang dilakukan mahasiswa untuk mendapatkan jawaban dari permasalahan yang diberikan, khususnya proses metakognisi yang digunakan dalam pemecahan masalah tersebut. Sjutz (dalam Laurens, 2009) menjelaskan strategi yang dapat digunakan untuk mengontrol langkahlangkah metakognisi meliputi: proses perencanaan, pemantauan, dan penilaian. Keberhasilan mahasiswa dalam menyelesaikan masalah sangat tergantung pada kesadaran berpikirnya. Menurut Wilson (2004), kesadaran berpikir seseorang dapat diamati. Sehingga tingkat kesadaran berpikir siswa dapat diamati pada langkah-langkah yang dilakukannya dalam menyelesaikan suatu masalah, yakni proses perencanaan, pemantauan, dan penilaian.

Berdasarkan uraian di atas, maka ruang lingkup/tujuan penelitian ini adalah untuk (1) meninjau kesadaran metakognisi mahasiswa Jurusan Pendidikan Matematika FKIP UHO secara umum, (2) meninjau kesadaran metakognisi mahasiswa Jurusan Pendidikan Matematika FKIP UHO berdasarkan nilai UN Matematika di SMA, (3) meninjau kesadaran metakognisi mahasiswa Jurusan Pendidikan Matematika FKIP UHO berdasarkan asal SMA, dan (4) meninjau kesadaran metakognisi mahasiswa Jurusan Pendidikan Matematika FKIP UHO berdasarkan jenis kelamin.

\section{METODE PENELITIAN}

Populasi Penelitian ini adalah mahasiswa semester I Jurusan Pendidikan Matematika FKIP UHO Angkatan 2015, terdiri dari kelas A (Stambuk ganjil) berjumlah 63 orang dan kelas B (Stambuk genap) berjumlah 62 orang. Sedangkan sampel dalam penelitian ini adalah mahasiswa semester I kelas A Jurusan Pendidikan Matematika FKIP 
UHO karena mahasiswanya berasal dari berbagai jenjang sekolah menengah atas di Sulawesi Tenggara bahkan ada di luar Sulawesi Tenggara. Dari 63 orang mahasiswa terdapat 29 orang berdomisili di ibu kota provinsi maupun kabupaten, dan 34 orang berdomisili di luar kota.

Pada awal perkuliahan diberikan tes dengan materi matakuliah matematika dasar (Kalkulus Differensial) ditinjau dari 3 aspek berdasarkan objek matematika, yakni berdasarkan konsep, prinsip, dan algoritma. Tes ini bertujuan untuk menelusuri level atau tingkatan kesadaran metakognitif mahasiswa apakah berada pada level 1, level 2, level 3, atau level 4.

Indikator untuk menelusuri level atau tingkatan metakognitif mahasiswa, mengikuti adaptasi Lauren (2009) sebagai berikut:

1. Tacit use (penggunaan pemikiran tanpa kesadaran):

Indikator perencanaan, yaitu: mahasiswa tidak dapat menjelaskan apa yang diketahui, mahasiswa tidak dapat menjelaskan apa yang ditanyakan, dan mahasiswa tidak dapat menjelaskan masalah dengan jelas. Indikator pemantauan, yaitu: mahasiswa tidak menunjukan adanya kesadaran terhadap apa saja yang dipantau dan mahasiswa tidak menyadari kesalahan pada konsep dan hasil yang diperoleh. Indikator penilaian, yaitu: mahasiswa tidak melakukan evaluasi atau jika melakukan evaluasi akan tampak bingung atau ketidakjelasan terhadap hasil yang diperoleh.

2. Aware use (penggunaan pemikiran dengan kesadaran):

Indikator perencanaan, yaitu: mahasiswa mengalami kesulitan dan kebingungan karena memikirkan konsep (rumus) dan cara menghitung yang akan digunakan, mahasiswa hanya menjelaskan sebagian dari apa yang ditulis, dan mahasiswa memahami masalah karena dapat mengungkapkan dengan jelas. Indikator pemantauan, yaitu: mahasiswa mengalami kebingungan karena tidak dapat melanjutkan apa yang akan dikerjakan, mahasiswa menyadari kesalahan konsep (rumus) dan cara menghitung namun tidak dapat memperbaikinya. Indikator penilaian, yaitu: mahasiswa tidak melakukan evaluasi atau jika melakukan evaluasiakan tampak bingung atau ketidakjelasan terhadap hasil yang diperoleh dan mahasiswa melakukan evaluasi namun tidak yakin terhadap hasil yang diperoleh.

3. Strategic use (penggunaan pemikiran yang bersifat strategis):

Indikator perencanaan, yaitu: mahasiswa memahami masalah karena dapat 
mengungkapkan dengan jelas, mahasiswa tidak mengalami kesulitan dan kebingungan untuk menemukan rumus dan cara menghitung, dan mahasiswa dapat menjelaskan sebagian besar apa yang dituliskannya. Indikator pemantauan, yaitu: mahasiswa menyadari kesalahan konsep dan cara menghitung dan mahasiswa mampu memberi alasan yang mendukung pemikirannya. Indikator penilaian, yaitu: mahasiswa tidak melakukan evaluasi atau jika melakukan evaluasi akan tampak bingung atau ketidakjelasan terhadap hasil yang diperoleh dan mahasiswa melakukan evaluasi namun kurang yakin dengan hasil yang diperoleh.

4. Reflective use (penggunaan pemikiran yangbersifat reflektif):

Indikator perencanaan, yaitu: mahasiswa mengetahui cara yang digunakan untuk menyelesaikan masalah, mahasiswa mampu menjelaskan strategi yang digunakan untuk menyelesaikan masalah, mahasiswa memahami masalah dengan baik karena dapat mengidentifikasi informasi penting dalam masalah, dan mahasiswa dapat menjelaskan apa yang ditulis pada lembar jawaban. Indikator pemantauan, yaitu: mahasiswa mampu mengaplikasikan strategi yang sama pada masalah yang lain dan mahasiswa menyadari kesalahan konsep yang dilakukan dan dapat memperbaikinya. Indikator penilaian, yaitu: mahasiswa melakukan evaluasi terhadap setiap langkah yang dibuat dan meyakini hasil yang diperoleh.

\section{HASIL DAN PEMBAHASAN}

Sesuai permasalahan di atas, maka hasil penelitian diuraikan dalam empat kategori, yaitu: (1) Tinjauan Kesadaran Metakognisi mahasiswa Jurusan Pendidikan Matematika FKIP UHO secara umum, (2) Tinjauan Kesadaran Metakognisi mahasiswa Jurusan Pendidikan Matematika FKIP UHO berdasarkan nilai UN Matematika, (3) Tinjauan Kesadaran Metakognisi mahasiswa Jurusan Pendidikan Matematika FKIP UHO berdasarkan Asal SMA, dan (4) Tinjauan Kesadaran Metakognisi mahasiswa Jurusan Pendidikan Matematika FKIP UHO berdasarkan Jenis Kelamin.

1. Tinjauan Kesadaran Metakognisi mahasiswa Jurusan Pendidikan Matematika FKIP UHO secara umum

Adapun tingkatan kedasaran metakognisi mahasiswa Jurusan Pendidikan Matematika FKIP UHO seperti tabel 1 berikut ini. 
Tabel 1. Tingkat Kesadaran Metakognisi mahasiswa Jurusan Pendidikan Matematika FKIP UHO secara umum

\begin{tabular}{llcc}
\hline No. & $\begin{array}{l}\text { Level Kesadaran } \\
\text { Metakognisi }\end{array}$ & $\begin{array}{l}\text { Jumlah } \\
\text { siswa }\end{array}$ & Persentase \\
\hline 1. & Level 1: tacit use & 34 & $53,9 \%$ \\
\hline 2. & Level 2: aware use & 13 & $20,7 \%$ \\
\hline 3. & Level 3: strategic use & 8 & $12,7 \%$ \\
\hline 4. & level 4 : reflective use & 8 & $12,7 \%$ \\
\hline
\end{tabular}

Berdasarkan tabel 1 di atas, terlihat bahwa sebagian besar (53,9\%) Tingkat Kesadaran Metakognisi mahasiswa Jurusan Pendidikan Matematika FKIP UHO berada pada level 1 (tacit use), dan sebagian kecil $(12,7 \%$ ) berada pada level 4 (reflective use).

2. Tinjauan Kesadaran Metakognisi mahasiswa Jurusan Pendidikan Matematika FKIP UHO berdasarkan nilai UN Matematika

Adapun tingkatan kedasaran metakognisi mahasiswa Jurusan Pendidikan Matematika FKIP UHO berdasarkan nilai UN Matematika seperti tabel 2 berikut ini.

Tabel 2. Tingkat Kesadaran Metakognisi mahasiswa Jurusan Pendidikan Matematika FKIP UHO berdasarkan nilai UN Matematika

\begin{tabular}{llccccc}
\hline & & & \multicolumn{4}{c}{$\begin{array}{c}\text { Kesadaran Metakognisi } \\
\text { Mahasiswa }\end{array}$} \\
\cline { 4 - 7 } No & \multirow{2}{*}{$\begin{array}{c}\text { Persen- } \\
\text { tase }\end{array}$} & $\begin{array}{c}\text { tacit } \\
\text { ase }\end{array}$ & $\begin{array}{c}\text { aware } \\
\text { use }\end{array}$ & $\begin{array}{c}\text { strategic } \\
\text { use (\%) }\end{array}$ & $\begin{array}{l}\text { reflective } \\
\text { use (\%) }\end{array}$ \\
& & & $\begin{array}{c}\text { use } \\
(\%)\end{array}$ & $(\%)$ & & \\
\hline 1. & $\mathrm{UN}<50$ & $16,28 \%$ & 71,44 & 14,28 & 14,28 & 0 \\
\hline 2. & $50 \leq \mathrm{UN}<70$ & $13,95 \%$ & 50,00 & 16,67 & 33,33 & 0 \\
\hline 3. & $70 \leq \mathrm{UN}<90$ & $55,82 \%$ & 62,50 & 12,50 & 4,17 & 20,83 \\
\hline 4. & $\mathrm{UN} \geq 90$ & $13,95 \%$ & 0 & 33,33 & 16,67 & 50,00 \\
\hline
\end{tabular}

Berdasarkan tabel 2 di atas, terlihat bahwa umumnya (55,82\%) mahasiswa Jurusan Pendidikan Matematika FKIP UHO yang memiliki nilai UN matematika dari 70 sampai 90, dan hanya 13,95\% memperoleh nilai UN matematika 90 ke atas. Dari nilai UN matematika mahasiswa yang kurang dari 90, umumnya masih berada pada level 1 (tacit use), sedangkan nilai UN matematika mahasiswa 90 ke atas umumnya sudah berada pada level 4 (reflective use).

3. Tinjauan Kesadaran Metakognisi mahasiswa Jurusan Pendidikan Matematika FKIP UHO berdasarkan Asal SMA

Adapun tingkatan kedasaran metakognisi mahasiswa Jurusan Pendidikan Matematika 
FKIP UHO berdasarkan asal SMA seperti tabel 3 berikut ini.

Tabel 3. Tingkat Kesadaran Metakognisi mahasiswa Jurusan Pendidikan Matematika FKIP UHO berdasarkan asal SMA

\begin{tabular}{llllccc}
\hline \multirow{2}{*}{ No. } & Asal & \multirow{2}{*}{ Persentase } & \multicolumn{4}{c}{ Kesadaran Metakognisi Mahasiswa } \\
\cline { 3 - 6 } & SMA & & tacit use & aware & strategic & reflective \\
use & use & use \\
\hline 1. & Kota & $46,03 \%$ & $44,83 \%$ & $20,69 \%$ & $10,34 \%$ & $24,14 \%$ \\
\hline 2. & Luar & $53,97 \%$ & $61,77 \%$ & $20,59 \%$ & $14,7 \%$ & $2,94 \%$ \\
& Kota & & & & & \\
\hline
\end{tabular}

Berdasarkan tabel 3 di atas, terlihat bahwa umumnya $(53,97 \%)$ mahasiswa Jurusan Pendidikan Matematika FKIP UHO berdomisili di luar kota. Dan dari mahasiswa yang berdomisili diluar kota tersebut, umumnya $(61,77 \%)$ tingkat kesadaran metakognisi mahasiswa masih berada pada Level 1 (tacit use), dan hanya 2,94\% berada pada level 4 (reflective use). Sedangkan mahasiswa yang berdomisili di kota, tingkat kesadaran metakognisi mahasiswa yang berada pada Level 1 (tacit use) hanya 44,83\%), dan pada level 4 (reflective use) ada 24,14\%.

4. Tinjauan Kesadaran Metakognisi mahasiswa Jurusan Pendidikan Matematika FKIP UHO berdasarkan Jenis Kelamin

Adapun tingkatan kedasaran metakognisi mahasiswa Jurusan Pendidikan Matematika FKIP UHO berdasarkan jenis kelamin seperti tabel 4 berikut ini.

Tabel 4. Tingkat Kesadaran Metakognisi mahasiswa Jurusan Pendidikan Matematika FKIP UHO berdasarkan jenis kelamin

\begin{tabular}{lllllll}
\hline No. & Jenis & Persentase & \multicolumn{4}{c}{ Kesadaran Metakognisi Mahasiswa } \\
\cline { 3 - 6 } & & & tacit use & aware & strategic & reflective \\
Kelamin & & & & use & use \\
\hline 1. & Laki-laki & $36,51 \%$ & $52,18 \%$ & $21,74 \%$ & $13,04 \%$ & $13,04 \%$ \\
\hline 2. & Perempuan & $63,49 \%$ & $55,00 \%$ & $20,00 \%$ & $12,50 \%$ & $12,50 \%$ \\
\hline
\end{tabular}

Berdasarkan tabel 4 di atas, terlihat bahwa umumnya $(63,49 \%)$ mahasiswa Jurusan Pendidikan Matematika FKIP UHO adalah perempuan. Sedangkan tingkat kesadaran metakognisi mahasiswa antara laki-laki dan perempuan relatif sama, yakni: untuk laki-laki, Level 1 (tacit use) ada 52,18\%, Level 2 (aware use) ada 21,74\%, Level 3 (strategic use) ada 13,04\%, dan level 4 (reflective use) ada 13,04\%. Dan untuk perempuan, Level 1 (tacit use) ada 55,00\%, Level 2 (aware use) ada 20,00\%, Level 3 (strategic use) ada 12,50\%, dan level 4 (reflective use) ada $12,50 \%$. 


\section{SIMPULAN DAN SARAN}

Berdasarkan hasil penelitian dan pembahasan di atas, dapat disimpulkan bahwa:

1. Umumnya $(53,9 \%)$ Tingkat Kesadaran Metakognisi mahasiswa Jurusan Pendidikan Matematika FKIP UHO berada pada level 1 (tacit use), dan sebagian kecil $(12,7 \%)$ berada pada level 4 (reflective use).

2. Umumnya $(55,82 \%)$ mahasiswa Jurusan Pendidikan Matematika FKIP UHO yang memiliki nilai UN matematika antara 70 sampai 90, dan hanya 13,95\% memperoleh nilai UN matematika 90 ke atas. Dari nilai UN matematika mahasiswa yang kurang dari 90, umumnya masih berada pada level 1 (tacit use), sedangkan nilai UN matematika mahasiswa 90 ke atas umumnya sudah berada pada level 4 (reflective use).

3. Umumnya $(53,97 \%)$ mahasiswa Jurusan Pendidikan Matematika FKIP UHO berdomisili di luar kota. Dan dari mahasiswa yang berdomisili diluar kota tersebut, umumnya $(61,77 \%)$ tingkat kesadaran metakognisi mahasiswa masih berada pada Level 1 (tacit use), dan hanya 2,94\% berada pada level 4 (reflective use). Sedangkan mahasiswa yang berdomisili di kota, tingkat kesadaran metakognisi mahasiswa yang berada pada Level 1 (tacit use) hanya 44,83\%), dan pada level 4 (reflective use) ada $24,14 \%$.

4. Umumnya $(63,49 \%)$ mahasiswa Jurusan Pendidikan Matematika FKIP UHO adalah perempuan. Sedangkan tingkat kesadaran metakognisi mahasiswa antara laki-laki dan perempuan relatif sama.

\section{DAFTAR RUJUKAN}

Biryukov, P., 2003, Metacognitive Aspect of Solving Combinatorics Problems. [Online]. http://www.cimt.pymouth.ac.uk/journal/biryukov.pdf

La Misu, 2015, Strategi Pengembangan Metakognisi Mahasiswa dalam Mempelajari Teori Bilangan Berdasarkan Model Pembelajaran Perilaku, Pendidikan Matematika UMP- Purwokerto, 12 Desember 2015, (Prosiding)

Laurens,Theresia, 2009, Penjenjangan Metakognisi Siswa, Disertasi. Universitas Negeri Surabaya.

Swartz, Robert J. and Perkins, D. N, 1989, Teaching Thinking: Issues and Approaches. Revised Edition. The Practitioners' Guide to Teaching Thinking Series.

Wilson, Jeni dan Clark, David. 2004. Toward the Modelling of Mathematical 
Metacognition. Mathematics Education Research Journal, 2004, Vol. 16, No. 2, 25 48, University of Melbourne. 